\begin{tabular}{c} 
Volume and Issues Obtainable at Center for Sustainability Research and Consultancy \\
Journal of Business and Social Review in Emerging Economies \\
ISSN: 2519-089X (E): 2519-0326 \\
Volume 5: No. 1, June 2019 \\
CSRᄃ \\
Journal homepage: www.publishing.globalcsrc.org/jbsee \\
\hline
\end{tabular}

\title{
Foreign Policy and Afrocentricism: An Appraisal of Nigeria's Role
}

\author{
${ }^{1}$ Muritala Dauda , ${ }^{2}$ Mohammad Zaki Bin Ahmad , ${ }^{3}$ Mohammad Faisol Keling \\ ${ }^{1} \mathrm{Ph} . \mathrm{D}$ Candidate, School of International Studies, College of Law, Government and International Studies \\ (COLGIS), Universiti Utara Malaysia (UUM). The Corresponding email address: kalmurtala@gmail.com. \\ ${ }^{2}$ Senior Lecturer, School of International Studies, College of Law, Government and International Studies \\ (COLGIS), Universiti Utara Malaysia (UUM).
}

\begin{tabular}{l}
\multicolumn{1}{c}{ ARTICLE DETAILS } \\
\hline History \\
Revised format: May 2019 \\
Available Online: June 2019 \\
\\
\hline Keywords \\
Foreign Policy, Afrocentrism, \\
National Interest, Diplomacy, \\
Stability
\end{tabular}

JEL Classification:

L50, L52,L59, C62

\begin{abstract}
Nigerian foreign policy is a tool use by the country to achieve its national interest. The country's external policy has been tailored to be Afrocentric since its independence in 1960 which shows the commitment of Nigeria towards Africa's stability and development. The principles of Nigeria's foreign policy and its Afrocentricism has consistently operated by the government of the country irrespective of whether it is civilian or military administration. The notion of four concentric circle of Nigerian foreign policy where the country considers its national interest and the interest of its neighbouring States first, the West African sub-region, Africa's interest and the interest of the world, have accrued numerous benefits to the country. The benefit of Nigeria's Afrocentric policy has enormously assisted the country's image internationally. This has invariably promoted Nigeria's influence during global decision making. The study makes use of systems theory that viewed an individual or group as an ecosystem with moving parts that affect each other. Meaning that, if any part of human body is suffering from pain or any deficiency, the entire body will be feeling pain which can make the whole human body to malfunction. Likewise Nigeria, if any African country is in a crisis, all countries in Africa should look for a way-out to rescue the situation. The study therefore is qualitative in nature that employs the use of both primary and secondary data source. Twelve respondents were interviewed from various higher institutions and government agencies, and the data was analyzed thematically through Nvivo 10.
\end{abstract}

(C) 2019 The authors, under a Creative Commons AttributionNonCommercial 4.0

Corresponding author's email address: kalmurtala@gmail.com

Recommended citation: Dauda, M., Ahmad, M.Z.B., and Keling, M.F. (2019). Foreign Policy and Afrocentricism: An Appraisal of Nigeria's Role. Journal of Business and Social Review in Emerging Economies, 5 (1), 107-124

DOI: $10.26710 /$ jbsee.v5i1.511

\section{Introduction}

The foreign policy of all nations indicates the national interest to be pursue by the country. Similarly, the objective of such policy is part of the determinant factors of the country's image at the global system. Nigeria like many other countries of the world, has been purposive on this, which yielding positively to the country. This is because both actions and reactions of Nigeria to issues concerning it, is arguably guided by its foreign policy objectives. Apart 
from the issues affecting Nigeria, the country also ensure that Africa matters are adequately taken care of in its foreign policy objectives. In other word, Nigeria's favourable policy towards Africa has given it an edge over other countries in the continent.

According to Osuntokun (2007), Nigeria's foreign policy during the first republic was founded on "constructive Pan-Africanism" (p.1). This was pattern of Nigerian foreign policy during the first republic before it was changed from constructive Pan-Africanism to concentricism. The concentricism according to Nigerian former minister of foreign affairs, Chief Ojo Maduekwe quoted in Ashaver (2014) as "citizen foreign policy" (p.2). The concentric notion of Nigeria's foreign policy was formulated by Gambari where he observed the tensions and dynamics that has characterized the Nigeria's external policy which has resulted to a reduction in Nigeria's revenue on oil internationally (Ashaver, 2014). Gambari observed that reduction on Nigeria's oil revenues have exposed the country into some economy difficulties in the countries relations with West Europe and the United States. For that reason, he argued that Nigeria's foreign policy should be centred on four concentric circle. Meaning that, Nigeria shall consider its interest first, the interest of West African sub-region as second, the interest of Africa as its third priority and lastly, the interest of the entire world (Gambari, 1989; 2017).

As a result of this changes in Nigeria's external revenue on oil, Gambari came up with a notion called a concentric circle designed for the country's foreign policy to survive (Gambari, 1989; Amuwo, 2016). Hence, the survival of Nigeria's foreign policy through its concentric circle have made it visible for the country to contribute immensely to the African development, and in particular the stability needs in the African continent. The role of Nigeria in Africa, both at the continental and regional levels have showcase Nigeria's potential and commitment/passion for African unity, development, and stability.

Thus, this study seeks to appraise Nigeria's role in African continent through its afrocentric foreign policy to ensure unity and stability in the continent. In other word, Nigeria's favourable external policy to Africa continent, has exposed the country into series of commitment and responsibility that should be fulfilled in order to achieve the goals and objectives set to be realized by the African Union as a continental organization. Although, this responsible on Nigeria through its Afrocentric foreign policy requires series of sacrifices from the country such as manpower/personnel and monetary/material resources which are to be provided in order to carry out the development and stability tasks in Africa. It is against this backdrop the study is appraising Nigeria's role in Africa through its foreign policy tailored to promote peace, stability and development in the continent.

\section{Statement of Problems}

As described by Northedge (1968), a country foreign policy is "interplay between the outside and inside" (p. 15). This arguably shows that foreign policy of a country is one of the determinant factors for countries to relate with one another. The foreign policy of Nigeria has influenced the action and decision of the country on the issues in African continent. This has also made Nigeria a reckoning point for any meaningful development in Africa. Hence, this has canvassed for a number of studies on Nigeria's foreign policy such as Inamete (2001), Osuntokun (2007), Ashaver (2014) and Gambari (2017) where the study focused on how Nigeria's foreign policy has influenced the country in terms of decision making process. Similarly, studies like Fayome, Chidozie and Yartey-Ajayi (2015), Abdulrasheed, Muda and Ahmad (2016) viewed Nigeria's foreign policy on the perspective of leadership personality that is ruling the country. Also, Cilliers, Schunemann, and Moyer (2015), Ogunnubi and Isike (2015), Ogunnubi and Okeke-Uzodike (2016), and Ogunnubi (2017) concentrated their search towards whether Nigeria deserves to be addressed as hegemon through its designated role by its foreign policy on African matters.

However, it was discovered from the literature that limited studies appraised Nigeria's action and decision in Africa which its foreign policy mandate on the country as part of its responsibility in the African continent. Irrespective of the system of government/administration Nigeria is operating (either military or civil rule), the principle and notion of its concentric external policy remain the same. As a result of this therefore, the study appraises Nigeria's role in Africa through its foreign policy tailored to promote peace, stability and development in the continent.

\section{Methodology}

The study adopts a systematic review of literature focuses on foreign policy, diplomacy and national interest with emphasis on Nigeria. The study is a qualitative type that utilize both primary and secondary data sources. The primary sources of data involve the views of experts gathered through interview granted to professionals in the field of international relations. Similarly, the literature on Nigeria's foreign policy settings reported in journal articles, 
books, policy documents, Newspapers among others, are parts of the secondary sources in which data for this study are generated from.

Furthermore, the study makes use of systems theory to appraise the Nigeria's role through its foreign policy structured to promote stability and development in Africa. Similarly, the theory is used to analyze perhaps the reason and benefit of the Afrocentric foreign policy of Nigeria to the country and to the entire Africa at large. Systems theory is also known as the systems science. It is originated from biological sciences by its founders Bertalanffy Ludwing and Maturana Humberto (Boulding, 1956; von Bertalanffy, Ludwig, 1974). It was later employed by many disciplines to investigate phenomena from a holistic perspective. Scholars who subscribe to systemic perspective of analyzing events, believe that it is impossible to understand an event or issue by breaking it into small components. Rather, they assumed that global assessment is require to understand phenomenon. The scholars viewed an individual or group as "an ecosystem with moving parts that affect each other" (Adams, Hester \& Bradley, 2013). The theory is featured in a group of parts that interact to form a coherent whole. It is also described as having a "distinct boundary separating the system from external elements and distinguishing between inputs, or factors that impact the system, and outputs, or effect and products of the system" (Mele, Pels \& Polese, 2010, p.130).

The systems theory is emphasizing on the connectivity of every part of the system with one another. Meaning that, if any part of human body is suffering from pain or any deficiency, the entire body will be feeling such pain which arguably can make the whole human body to malfunction. Therefore, the theory is relevant to the study due to the fact that, the foreign policy of Nigeria is designed is such a way that the country will be concerned with happening within Africa. This is because, it maybe irrational for Nigeria not to show concern over any problem/difficulty that maybe encountered by any African countries, particularly the neighbouring States (Ashaver, 2014; Dauda, Sakariyau \& Ameen, 2018). Apart from being irrational if Nigeria turn a blind eye to the problems facing by other African countries, the aftermath of such problems on Nigeria will be greater than the cost to be incurred if the country in crisis is rescue on time (Wapmuk, 2014). Hence, another relevance of systems theory to the study is that it serves as a protective signal to Nigeria. This is because, the theory assists Nigeria on the needs to maximize its favour or benefit to other African countries which at the same protecting the country from sharing or inheriting products of such crises (like refugees, insurgence, terrorism, and other social vices) from other country.

\section{Conceptual Clarifications 4.1 Foreign Policy}

Foreign Policy: As argued by Enuka and Odife (2009) foreign policy is shaped by two determinants, (the foreign and the domestic). This influenced Adeniji (2000) to stressed that "the external factor i.e. the nature of the international system in which nations operate, primarily determines the foreign policy of especially the developing countries" (p.34). He expressed further that, "this is a reality to which African countries have to adjust" (p.34). Another scholar, Tyoden, (1989) posited that socio-political domestic milieu is a crucial determinant of foreign policy. This indicates that aside from the impel of foreign policy machinery, there are other domestic factors that are significance to be considered in the formulation of foreign policy. These include the organization and government's nature, political institutions and ideal practice of socio-political customs of the society (Enuka \& Odife, 2009).

The term foreign policy is a strategy which was designed institutionally for the decision makers to guide their actions within the international environment in order to achieve the country's national objectives (Ota \& Ecoma, 2015). It can also be described as an actions and reactions of a Nation to event in the international environment and internal circumstances towards the policy is formulated. This is argued by Ota and Ecoma (2015) that "a State in the international system can either precipitate an event in the external environment to which other actors would react or react to events precipitated by other state or non-state actors" (p.57). Franknel (1975) equally opined that county's foreign policy encompasses its general commitments and attitudes toward the international environment, and country's strategy to realize both the internal and external aspirations and objectives.

As entrenched in the 1999 Constitution of Nigeria under Chapter 2, Section 19(a-e) which stated the fundamental objectives and principles of Nigeria's foreign policy as follows: (a) promotion and protection of the national interest; (b) promotion of African integration and support for African unity; (c) promotion of international cooperation for the consolidation of universal peace and mutual respect among all nations, and elimination of discrimination in all its manifestations; (d) respect for international law and treaty obligations as well as the seeking 
of settlement of international disputes by negotiation, mediation, conciliation, arbitration and adjudication; and (e) promotion of a just world order (1999 Constitution of the Federal Government of Nigeria; Saliu, 2013, p. 171; Akindele, 2013, p.13). These objectives of Nigeria's foreign policy mentioned have been followed consistently by the country towards its action and reaction in the African continent (Gambari, 1986; Ogwu, 1986; Akinyemi, 1989; Akindele, 1990; Saliu, 1999; Ayam, 2010). Also, supported the claim is Akinboye (2013) who argued that:

It is very clear that there is continuity across regimes in spite of changes in the pursuit of national interest. There is constancy in Nigeria's foreign policy objectives and foreign relations from the civilian regime of Prime Minister Abubakar Tafawa Balewa to President Goodluck Jonathan (p.13).

Beyond that, it is arguable that the present administration in Nigeria under President Muhammadu Buhari is adopting similar objectives toward the country's relationship with the international community.

\subsection{Diplomacy}

Diplomacy: The term diplomacy has been viewed differently by many scholars. Satow (1966) described diplomacy as "the application of intelligence and tact to the conduct of official relations between the governments of independent states" (p.1). However, the view of Satow on diplomacy was faulted on the basis that not all diplomats are intelligent or skillful, but they participated either in one way or the other in the diplomatic process (Ogunsanwo, 2007). McDermott (1973) viewed diplomacy as "a science which permits its practitioners to say nothing and shelter behind mysterious nods of the head..., a science who's most successful exponent is he who can swim with his head above streams of events he pretends to conduct" (p.37). Morgenthau equally asserts diplomacy as "the technique for accommodating conflicts of interest, and the promotion of national interest by peaceful means" (1978, p.529).

Plischke (1977) capped it all by defining diplomacy as "the political process whereby States establish and nurture official interrelations, direct and indirect, to pursue their respective goals, interest and substantive and procedural policies in the international environment" (p.41). Similarly, Ota and Ecoma (2015), described it as a system of negotiation and communication between State and other actors who are non-state, and ready to engage in the international relations through cooperation to provide remedy to contentious issues rather than engaging in war.

\subsection{National Interest}

National Interest: The term is mostly used to prescribed and at the same time described foreign policy (Nye Jr, 1999). According to Huntington (1997), "without a sure sense of national identity, Americans have become unable to define their national interests, and as a result subnational commercial interests and transnational and nonnational ethnic interests have come to dominate foreign policy" (p.29). Similarly, the Commission on America's National Interests have put it straight in 1996 when it declared that, "national interests are the fundamental building blocks in any discussion of foreign policy.... In fact, the concept is used regularly and widely by administration officials, members of Congress, and citizens at large" (Nye Jr, 1999, p.23).

Under a democratic system of government, a country's national interest can be arguably described as a set of priorities that guides the relationship of a country with the rest of the world. Ota and Ecoma (2015) equally argued that country's foreign policy is one of the determinants that shape the principle of national interest. He stressed further that national interest encompasses some "values and ideals which a nation so cherishes that she would rather go to war than compromise" (p.57). Foreign policy defends national interest through diplomacy, but when diplomacy fails, the former can be defended through war and the force of arms. Other component of national interest includes, sovereignty, territorial integrity, political culture, citizens' welfare among others.

\section{Historical Background of Nigerian Foreign Policy and Africa's Centrepiece Policy}

The foreign policy of Nigeria has its origin dated back to its independence in 1960. The objectives and principles of Nigeria's foreign policy was articulated and elaborated by the country's Prime Minister, Alhaji (Sir) Abubakar Tafawa Balewa in his address at the United Nations General Assembly to mark Nigeria's admission as 99th member of the organization on 8th October, 1960 (Ota \& Ecoma, 2015). Similarly, Jaja Wachukwu's appointment as Nigeria's First Minister of Foreign Affairs and Commons (the ministry was later named as External Affairs), affirmed Africa as the country's focus of foreign policy. The fundamental principles of Nigeria's foreign policy were later affirmed and made clear by Jaja Wachukwu on 4th September, 1961 at the Federal House of Representatives. These principles includes: (a) to promote national interest and world peace; (b) to have Africa as the centre-piece of Nigerian foreign policy, with a view to achieving cooperation and progress among African 
States, and achieving total independence in all African states; (c) to promote international friendship, cooperation and neutrality; (d) to respect the sovereign equality of all states, irrespective of size, and to honour the principle of non-interference in other countries' internal affairs (Ota \& Ecoma, 2015, p.56).

As argued by Gambari (1989), Agbu, Okereke, Wapmuk and Adeniyi (2013), Nigeria's foreign policy since independence has undergone series of changes with exception to its principles which remain the same. The reason for changes in Nigeria's foreign policy was as a result of change of country's leadership or head. Despite the changes in the leadership of Nigeria, the country ensure that its foreign policy is Afrocentric which focusing more on political cooperation, economic development, amicable settlement of crisis within Africa (Folarin, 2013; Oni \& Taiwo, 2016). The personality interest and influence of leaders in Nigeria (either military or civilian rule) determines which country/countries outside Africa to relate with, which invariably shape its foreign policy directions (Ajayi, Njoaguani, Olorunyomi \& Folarin, 2015).

The personality and interest of a leader in a country play a crucial role in the determinants of foreign policy objective (Levy, 2013). Scholars like Gambari (1989, p.2; 2017, 12) and Adebajo (2008, p.7) argued that Nigerian leaders adopt the "notion of four concentric circles of national interest". The first circle is described as the innermost core which involves the security of Nigeria and its citizens' welfare. It also covers the maintenance of spirit of good neighbourliness with States that surrounded Nigeria like Chad, Benin, Niger and Cameroon. The second interest centered on Nigeria's relationship with West African countries located within ECOWAS subregion. Thirdly, the interest and commitment of Nigeria to the entire African continent, while the fourth one is the country's concern to the entire world through its membership to the organization outside Africa.

The leadership of Nigeria under Alhaji (Sir) Abubakar Tafawa Balewa as its first Prime Minister tailored the country's foreign policy to be Africa centrepiece policy. Balewa's administration operated pro-West style of foreign policy due to Nigeria's colonial lineage with Britain (Wogu, Sholarin \& Chidozie, 2015). The Balewa's administration was overthrown by a military government through coup on 15th January, 1966 led by General Johnson Aguiyi-Ironsi. The military government under Aguiyi-Ironsi was ousted after six months through another military coup which steered in General Yakubu Gowon as the new Head of government in Nigeria (Ajayi, Njoaguani, Olorunyomi \& Folarin, 2015). Gowon's government operated on Balewa's pro-West foreign policy style where the government signed treaties with Britain, United States and some Western countries with exception to the Soviet Union that Nigeria's government prevented its embassy in the country (Oni \& Taiwo, 2016).

The administration under General Gowon was toppled in another coup led by General Murtala Ramat Mohammad and General Olusegun Obasanjo as his Chief of Staff in 1975. The new government introduced a new innovation into Nigeria's foreign relations (Ogunsanwo, 1980; Ewoh, 2014). General Murtala's administration was conscious about the imperial plans of the Western power, especially the US. This made the administration to focused more on eradication of neo-colonialism, racism and apartheid from the continent of Africa, particularly in some Portuguese colonies (Dauda, Sakariyau \& Ameen, 2018). The Nigeria's commitment towards the eradication of racism by Murtala's administration was demonstration in his speech at the OAU extra-ordinary meeting that took place in Addis Ababa on 11th January, 1976 where he stressed that:

Mr. Chairman, when I contemplate the evils of apartheid, my heart bleeds and I am sure the heart of every true blooded African bleeds....Rather than join hands with the forces fighting for self-determination and against racism and apartheid, the United States policy makers clearly decided that it was in the best interests of their country to maintain white supremacy and minority regimes in Africa (Leadership Newspaper, 2016).

The foreign policy style operated under Murtala's government elevated Nigeria to serve as a regional power and at the same time project the country to be more important in Africa (Dickson \& Ezirim, 2017). Despite the fact that General Murtala was assassinated by Lieutenant Colonel Buka Suka Dimka in an unsuccessful coup which took place on 13th February, 1976, his Chief of Staff, General Obasanjo assumed the position of Head of State of Nigeria (Folarin, 2013).

The administration of General Obasanjo conducted an election which emerged Alhaji Shehu Shagari as Nigeria new elected president in 1979 (Nkem-Onyekpe, 2015). The administration of President Shagari upheld the existing Nigerian foreign policy principles. However, there was another coup which was led by Generals Muhammadu Buhari and Tunde Idiagbon. The military took over power from Shagari administration on 31st December, 1983 
with their agenda of promoting the image of Nigeria and its relations with other countries. Similarly, another military coup led by General Ibrahim Badamosi Babangida ousted Generals Buhari/Idiagbon's administration. The administration of General Babangida was described by Olowu (2017) to have canvassed for some setbacks in Nigerian foreign policy.

The administration of General Babangida introduced policies like Structural Adjustment Programme (SAP) that are not healthy for Nigeria's economy. The administration conducted an election in 1993 which was worldly considered to be free, fair and credible, but the result of the election was annulled by General Babangida regime which resulted to mass protests and demonstration by Nigerians both at home and abroad (Adegoju, 2014). The regime later handed over power to Chief Ernest Shonekan as an interim government on 26th August, 1993. The interim administration was overthrown by another military government led by General Sani Abacha (Yunusa, 2016). The administration of Abacha arguably contributed to the deteriorating image of Nigeria to extent of its pronounced corruption rate.

Nevertheless, the sudden death of General Abacha on 8th June, 1998 paved way for the assumption of power by General Abdulsalam Abubakar. The General conducted general election that produced Chief Olusegun Obasanjo as the Nigerian president on 29th May, 1999 (Collier \& Vicente, 2014). The government under President Obasanjo embarked on numerous foreign trips to the international community with the objective of correcting the dented image of Nigeria (Durotoye, 2015). The shuttle diplomacy of Chief Obasanjo's administration assisted Nigeria in many ways ranging from redeeming the country's image, debts waving/cancellation, opportunity to chair some meetings of AU, ECOWAS, G-17, among others (Lanre \& Olumide, 2015). This opportunity is arguable aid the Nigeria's foreign policy principle to be exercised.

Subsequently, Chief Obasanjo's administration was succeeded by another civilian government under Alhaji Umaru Yar'adua/Dr. Goodluck Jonathan in 2007. The administration of Dr. Goodluck Jonathan ensured its promote the good image of Nigeria to the global world before the administration was handed over power to another democratically elected government (Okeke \& Aniche, 2013). Since, the year 2015 when President Muhammadu Buhari took over power, his administration has been maintaining the existing principles of Nigerian foreign policy, particularly on the need for peace and stability in the African continent and the world at large (Amuwo, 2016).

Therefore, it can be argued that the continuous exercise of Nigerian foreign policy's principles, particularly the four concentric circles by both past and present government of the country is attesting to the notions and assumptions of systems theory. This is because, Nigeria has foreseen it that, if it fails to come into the rescue of the African countries, or the neighbouring States during their needs, it will be difficult for its national interest to be achieved. Thus, the willingness and commitment of Nigeria towards actualizing part of its foreign policy's objective of maintaining peace and stability in the Africa is arguably canvassed for its significant role played during the transformation of the Organization of African Unity (OAU) to AU. This also canvassed for Nigeria's role in formulation of Article 4(h) of the AU Constitutive Act which allows the organization and States to interfere in the internal affairs of other members whenever there is grave violation of human rights.

\section{Benefits of Nigerian Afrocentric Foreign Policy: An Examination of its Peace and Stability Function}

It can be argued that part of Nigerian foreign policy's objectives is to ensure peace and stability within the country and the entire Africa. Similarly, for the country to be able to achieve this objective, its foreign policy is tailored to be Afrocentric. This and many other reasons have influenced Nigeria's interest and commitment in Africa's stability which the country has been canvassing for other African countries to emulate such (Bello, Dutse \& Othman, 2017; Dauda, Ahmad \& Keling, 2017). It is argued that without peace and stability in an environment, there will be no room for any development in the area. This argument was buttressed by Nelson Mandela in his speech on April, 2000 that "what happens in Africa impacts on its relations with the world. Sustainable growth and development therefore requires peace, security and stability. And they require the unity of the African continent. Peace is the greatest weapon for development" (Marshall Plan Project Group, 2017, p.3).

Therefore, there are numerous benefits that Nigeria is deriving from its Afrocentric foreign policy towards ensuring peace and stability in Africa. These benefits are as follow: (a) security benefit; (b) citizen diplomacy; (c) sovereignty protection; (d) unity and cooperation; (e) international recognition and clout. Hence, figure 1.1 below 
indicates some benefits accrued to Nigeria due to its Afrocentric policy of ensuring stability in the African continent.

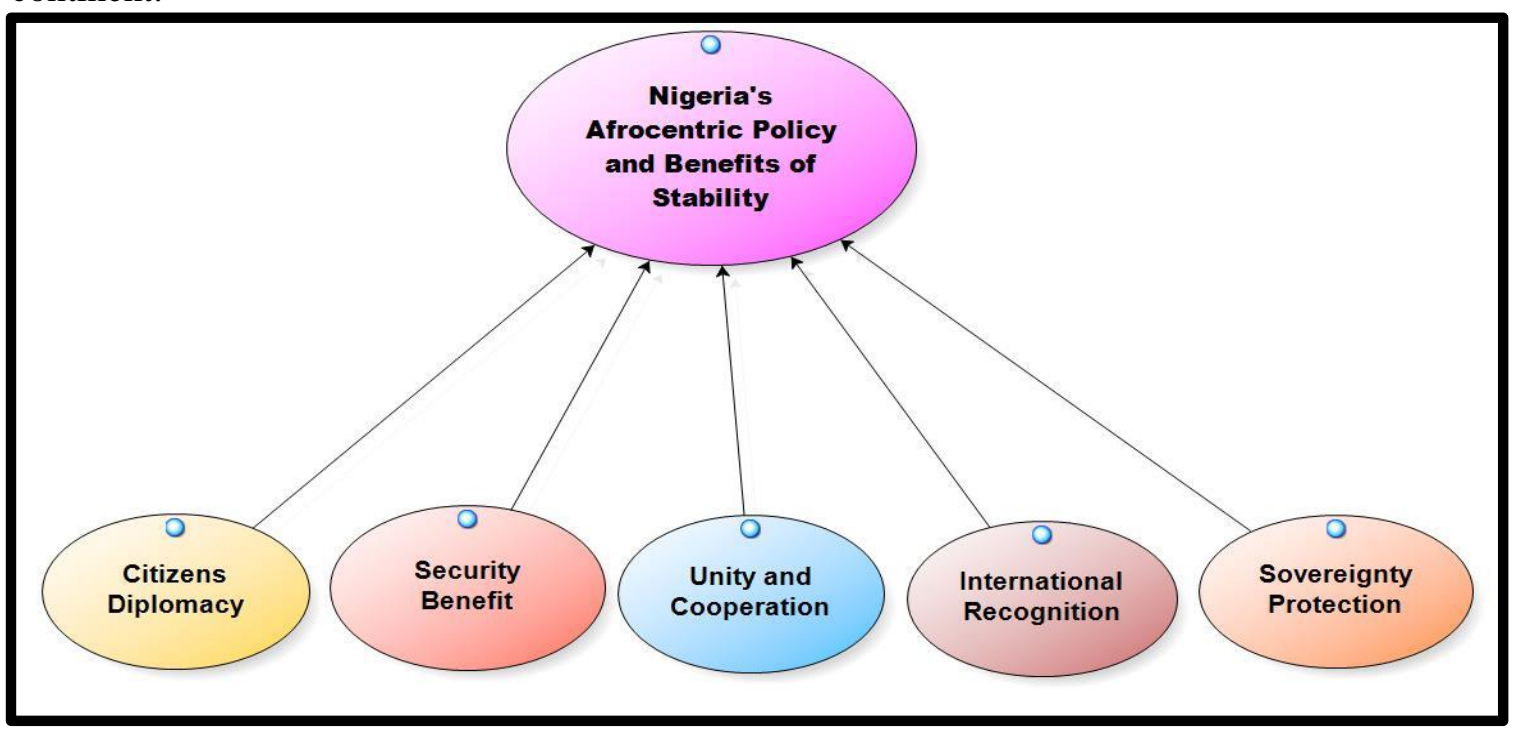

Figure 1.1. Nigeria's Afrocentric Policy and its Stability Benefits

\subsection{Security Benefit}

Security Benefit: security factor is one of the reasons for the frequent intervention of Nigeria to ensure peace reign in the African continent. As stipulated in the Nigerian foreign policy's principles in which its national interest could be achieved through the notion of four concentric circles propounded by Ibrahim Gambari, the country should be conscious and security-wise about the happenings around it (Achumba, Ighomereho \& Akpor-Robaro, 2013; Innocent \& Onyishi, 2014; Badiora, 2015). This means that, the earlier Nigeria addresses the security challenges within its environment, the better for the country and vice versa. As a result of this Nigeria is directly or indirectly protecting itself by assisting other neighboring countries to ensure stability and normalcy in their countries.

Informant NIIA1 has attested to the above function of Nigeria in ensuring stability in Africa as proclaimed by its foreign policy's principles. He argued that "wherever the needs for security in Africa falls within the concentric circles, Nigeria's national interest is realized. Wherever, there is peace and security, it is in Nigeria's interest to give in its supports". Similarly, another informant supported the above views that once Nigeria is in Africa:

A proverb says that if a neighbour house is on fire and one does not assist to keep off the fire, as time goes on, the fire will spread to one's home. So, there is a benefit that Nigeria ultimately derived by helping to secure other countries particularly in the West Africa region, the neighbouring countries. Doing this Nigeria is enhancing its security (Informant ABU2, personal communication, September 16, 2017).

Meaning that, Nigeria is protecting itself by contributing to peace and stability of another country in Africa. As argued by Ojakorotu and Adeleke (2018), "Nigeria contributed the highest troops and fund in defraying the cost of ECOMOG deployment in Liberia, Sierra Leone, Guinea-Bissau, Cote d'Ivoire, Mali among others" (p.37). This self-commitment to stability particularly among the neighbouring countries has made the former Head of State of Nigeria, General Ibrahim Babangida during his regime to have supported the need for peace during the Liberian conflict. He argued that:

The ECOWAS Region Constitutes concentric circles governing Nigerian foreign policy and defence policies - there is therefore no gain saying the fact that when certain events occur in this region depending upon their intensity and magnitudes where bound to affect Nigeria's policies Military and socio-economic environment, we should not stand - by as a hapless and helpless spectator. We believe that if the events are such that have the potentials to threaten the stability, peace and security of the sub-region, Nigeria is duty bound to react to either avert and disaster or to take adequate measures to ensure peace, tranquility and harmony (Bassey, 2011, p.7). 
Hence, the above submission can be argued that the involvement of Nigeria in maintaining stability in Africa, particularly the neighbouring countries, is to avert the spillover effect of such crisis from manifesting to the country.

As part of Nigeria's assistance to other African countries during their time of need, Ashaver (2014) argues that "Nigeria had granted a four billion and two billion naira loans to Ghana and Sao Tome and Principe respectively" (p.9). This according to Adeniji (2000) was done by Nigeria to those beneficiaries in exchange for a goal. Adeniji stated that:

For the Ghanaian deal, it is for execution of the West African pipeline project. When completed, it would help in gas distribution from Nigeria to other countries in the sub-region, thus boosting Nigeria's gas export. Turning to the two billion naira loan granted to Sao Tome and Principe, it is for a joint venture agreement whereby Nigeria could provide the expertise and operational workforce for the Sao Tome and Principe oil and gas venture (p.43).

Similarly, informant MFA1 stressed that "looking at the benefits that Nigeria is deriving from its stability role, one would rather say there are many benefits coming to the country". This indicates that Nigeria tend to benefit from its stability and developmental contribution to other countries in the African continent.

Contrary to the above view, it has been suggested that Nigeria should concentrate more on its efforts or actions that will fetch reward in return for the country because some of its beneficiaries mostly pay the country with ingratitude (Dauda, Ahmad \& Keling, 2017). This view is corroborated by Akinboye (2013) when he argues that:

Unfortunately and disappointingly, many of the countries that have benefitted tremendously from Nigeria's largess often turned around to show ingratitude to both its citizens and the government itself. ...South Africa exhibited xenophobic attack against Nigerian citizens living in that country... Besides, the countries it has supported financially, diplomatically and strategically becomes but the butt of derision and envy by them. Some of these countries equally harbour or even offer training facilities for terrorists, while others campaign openly against Nigeria's bid to occupy one of the permanent seats of the United Nations Security Council. From these instances, it has become clear that the age-long philosophical notion of Africa as the centre piece of the country's foreign policy has become moribund, mundane and anachronistic (pp. 43-44).

Another informant expressed that although some countries that benefited from Nigeria payback with ingratitude, but the country should not always expect reward or benefit for its action in Africa to come in a form of visible reward. He argued that:

Nigeria has been assisted other countries with no reward. In which they are expecting tangible or visible thing in terms of reward. The benefit to Nigeria for maintaining peace, security and stability in Africa is a long term. In fact, it even assists Nigeria. This is because, if there is crisis in neighbouring countries and Nigeria failed to show concern, a part from the fact that those countries may not come to Nigeria's aid during its need, the repercussion of the crisis such as refugees, social vices among others, will have a great influence on the country if it fails to act on time (Informant MFA1, personal communication, September 8, 2017).

The notion of not always expect reward to be in a form of tangible or visible reward is supported by Tambo, Ugwu and Ngogang (2014), Dauda and Ameen (2017) that, Nigeria's stability and developmental contribution in Africa maximize the country's security benefit. This has canvassed for the view of informant MFA2 that:

Nigeria's passion for peace and stability in Africa is normal because if Nigeria fails to be at alert on peace and security in Africa, the country will also share from the consequences. So, apart from the fact that Nigeria is making peace and ensuring stability in African continent, the country is also assisting itself, protecting itself from any spillover effects (Informant MFA2, personal communication, September 8, 2017). 
Informants MFA4, MFA3 and UniJos also argued that, it is for the national interest of Nigeria that make the country to be committed to the stability of the African continent. And by doing more to Africa in terms of stability, Nigeria is maximizing its benefits. Similarly, informant Unilorin was equally shared the view that Nigeria should always involve in the stability and developmental process in Africa. He added that:

Stability and peace are the foundation of progress, prosperity and development. Without a stable and peaceful continent, the aspiration of having a prosperous, progressive and developed Africa that is free from the words poverty and disease will remain a mirage. So, the benefit of peace and stability can never be overemphasized for Nigeria and for all other countries. Without peace and stability, you can hardly achieve any of the goals or objectives (Informant Unilorin, personal communication, August 28, 2017).

Hence, Nigeria's commitment to Africa's stability and development is described by Jordaan (2017) as an indirect way of waxing stronger of the country's security. Arguably, this is an advantage to Nigeria's security when compare with those that have not been involved in the stability struggle in the continent. Figure 1.2. below illustrates a consensus among the interviewees regarding security benefit as gain accrued to Nigeria due to its Afrocentric policy of ensuring stability in the African continent.

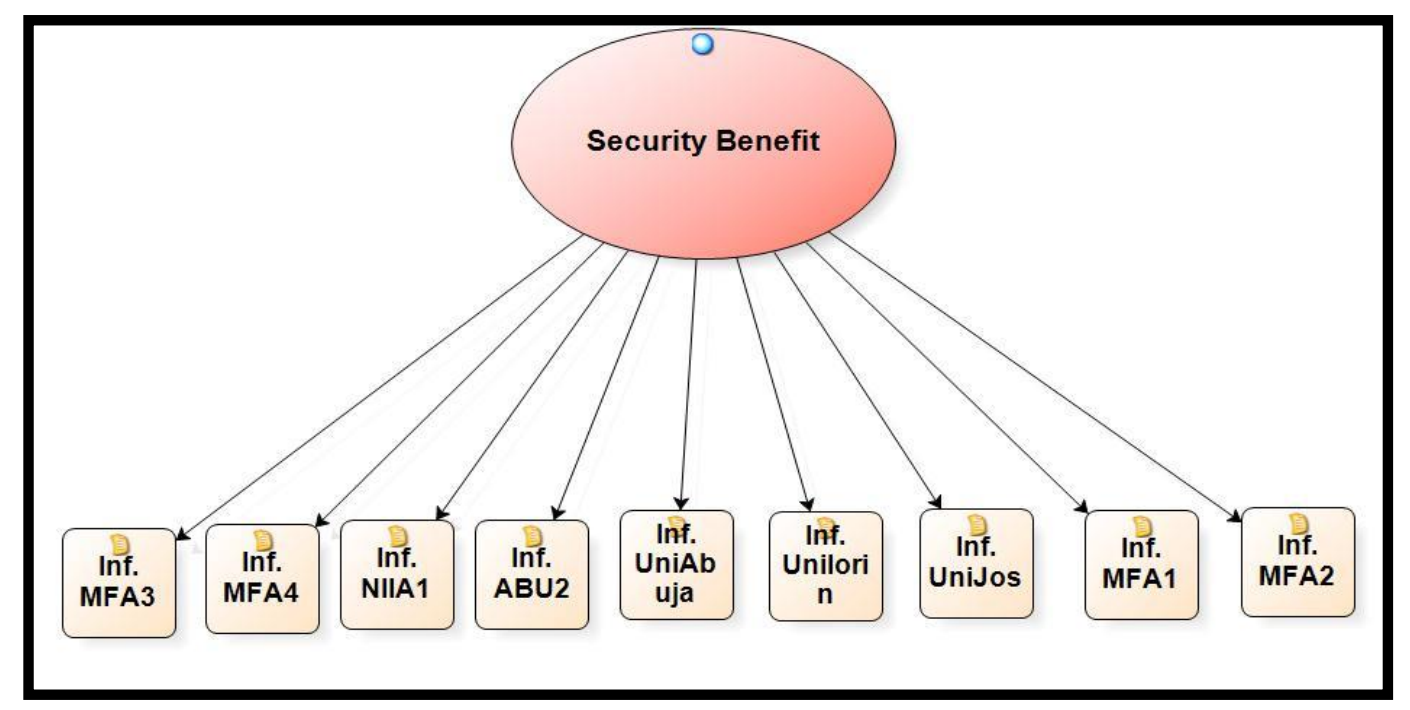

Figure 1.2. Security Benefit as Gain Accrued to Nigeria due to its Afrocentric Policy of Ensuring Stability in Africa

\subsection{Sovereignty Protection}

Sovereignty Protection: This is another benefit for Nigeria's involvement in ensuring African stability and development as entrenched in its foreign policy. As argued by Innocent and Onyishi (2014) that a State is considered protected when it is security conscious about its territorial boundary. This perhaps has made Nigeria to always forthcoming towards addressing any security challenges in the African continent.

An informant has expressed that "Nigeria is protecting its sovereignty by maintaining peace in Africa" (Informant BUK). The intervention of Nigeria in the crises of countries like Liberia, Sierra Leone, Guinea-Bissau and others was described by Kabia (2016) as an avenue to prevent the escalation of crises in those countries into its domain. The view argued by informant NIIA1 that "it is beyond that because sometime the understanding was that when such is allowed to thrive, it gives room for extra African power to keep intervening and meddling in the internal affairs of African countries".

As argued by Englehart (2017), Goldenziel (2017) and Yurchenko (2017), sovereignty is one of the essential features of a State, and its protection is mandatory for its survival. Similarly, scholars like Karimi, Koosha, Asfad and Ansari (2017) have argued that one of the assured ways for the protection of sovereignty and territorial integrity of a State is for that State to always support its neigbours in their struggle to ensure stability in the environments. This action expressed by Nigeria is what informant UniJos described as "peace loving in the African continent". 
Consequently, one can be argued that Nigeria's role in ensuring stability in Africa has directly or indirectly reduced the spillover rate of such crisis on the country. For example, Nigeria's impact towards the return of peace to Chad in between 1965-1979, and 2005-2010 can be attached to an act of preventing the country from sharing part of the likely products of crisis in Chad such as militants, refugees among others (Akinterinwa, 1987; Adetula, 2015). This action of Nigeria towards promoting stability and development in Africa has boost the country's image within the African continent and world at large. Therefore, figure 1.3. below shows a consensus among the interviewees regarding sovereignty protection as a benefit accrued to Nigeria due to its Afrocentric policy of ensuring stability in the African continent.

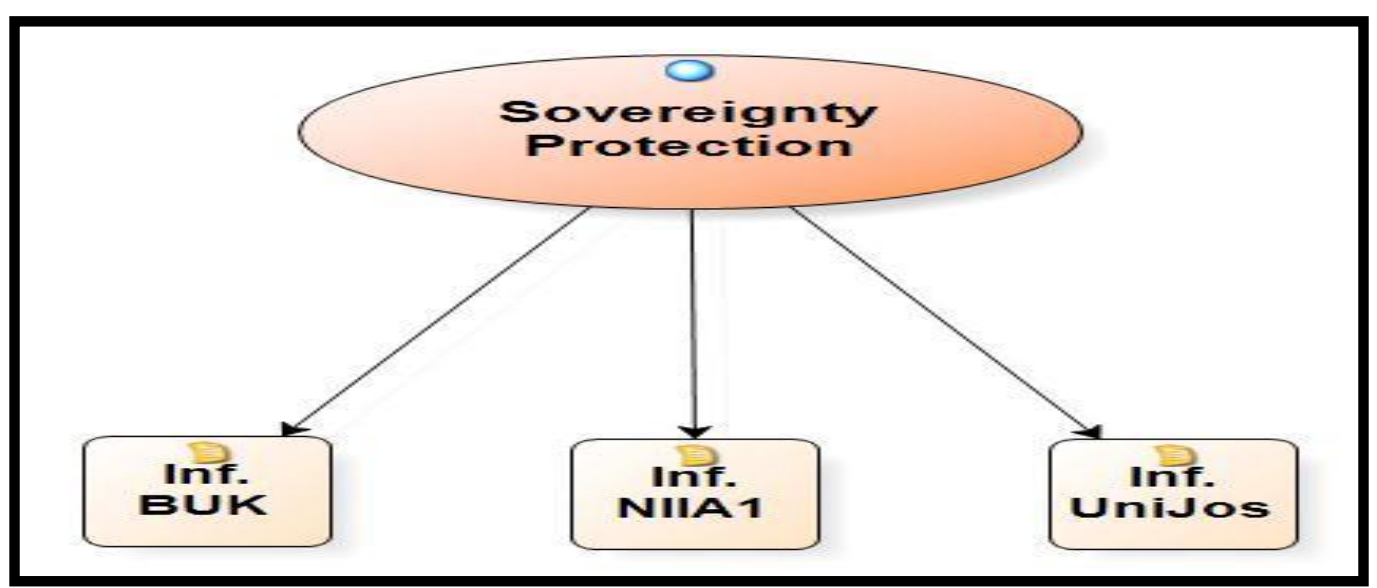

Figure 1.3. Sovereignty Protection as Benefit Accrued to Nigeria due to its Afrocentric Policy of Ensuring Stability in Africa

\subsection{International Recognition and Clout}

International Recognition and Clout: This is another benefit derived by Nigeria from its Afrocentric policy of foreign policy toward the continent. Many countries that Nigeria has in one way or the other assisted will always accord certain regards/respect for the country in all his aspiration (Dwyer, 2015). This according to Folarin (2013), Ashiru (2014), Fayomi, Chidozie and Ajayi (2015) canvassed for the recognition attached to Nigeria by the international community which invariably promote the global image of the country.

An informant has argued in support of the views that the leading role played by Nigeria particularly during most peacekeeping or stability operations in Africa has accounted for the trust and confidence of the global community on the country. He asserted that:

Nigeria's International recognition and clout not only in Africa, but among the committee of nations at the United Nations, the European Union, and others, make those organizations to respect Nigeria and reckoned with it particularly when it comes to peacekeeping exercises. This has made other African Nations to also respect Nigeria (Informant ABU1, personal communication, September 11, 2017).

Similarly, another informant urged Nigeria to increase its tempo and commitment in ensuring stability and development in Africa. This will promote Nigeria's influence during the decision making at the global level. He argued that:

The external projection of Nigeria is a tool to influence decision at the global level in favour of itself and Africa at large. This has accorded recognition to Nigeria and made it a place to reckon with when to address the instability in West Africa and in Africa at large. Nigeria has the intention, the Will, the capacity and the wherewithal to provide peace and stability (Informant ABU2, personal communication, September 16, 2017). 
Nigeria has been described by Adesoji (2016) as one-time largest troops contributor to the UN peacekeeping operations in Africa where it deployed both civilian and military personnel to assist in the return of peace back to many countries. This action of Nigeria has argued by informant NIIA1 to promote the country's prestige among other African countries. He posited that "international relations is more of game of the powerful against the weak". Therefore, it is possible for Nigeria to influence more at the global decision, if the country continues its developmental and stability function in the continent. Although, there are records that Nigeria had influenced great decisions in Africa. For example, at the AU 19th Ordinary Session held in Ethiopia on 15th-16th July, 2012 when the Chairman of the Commission was to be appointed. Nigeria was not in support of South African candidate Nkosazana Dlamini-Zuma but preferred Jean Ping, a candidate from Gabon. Nigeria ensured that it mobilized other African countries to vote in favour of Mr. Jean Ping, and the candidate eventually emerged as the Chairman of AU Commission. (Wapmuk, 2014).

Therefore, the influence commanded by Nigeria at the AU 19th Ordinary Session could be arguably described as an intangible benefit for the assistance the country had rendered to the Africa. It is an advantage for Nigeria to always improve its involvement towards ensuring development and stability in the African continent. Figure 1.4. below indicates a consensus among the interviewees regarding international recognition and clout as another benefit accrued to Nigeria due to its Afrocentric policy of ensuring stability in the African continent.

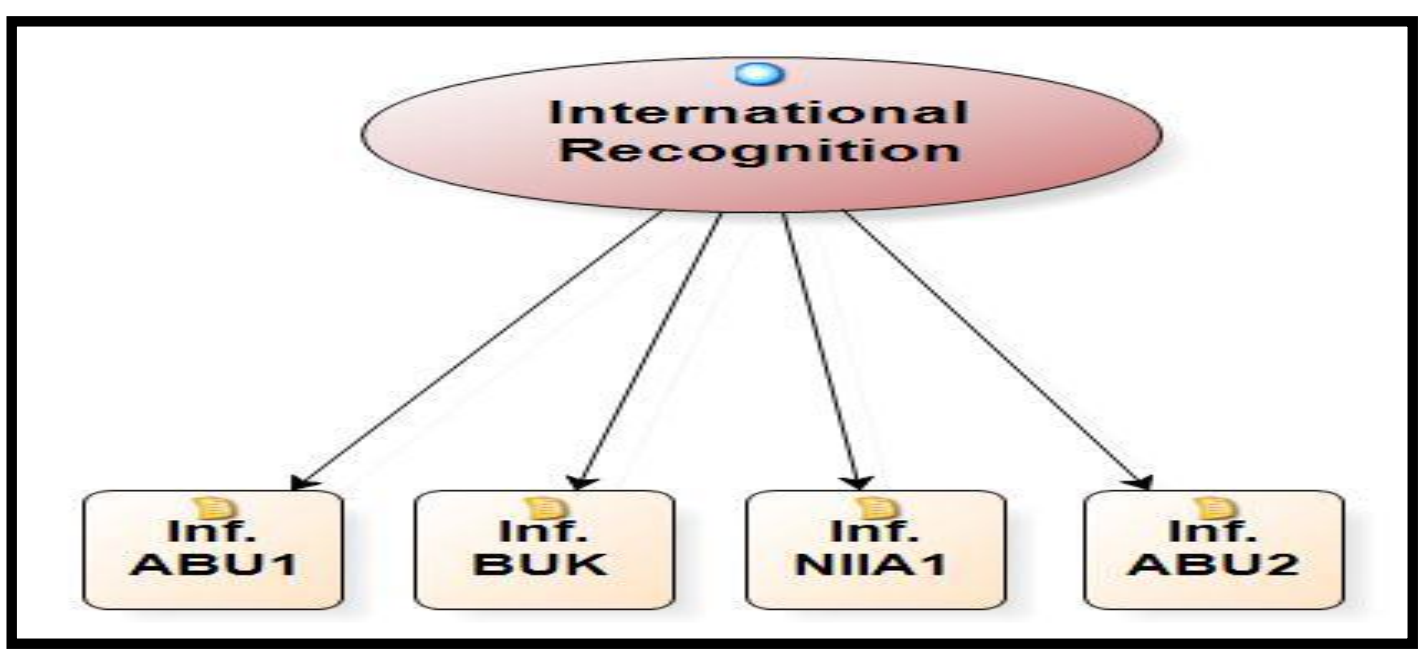

Figure 1.4. International Recognition and Clout as Benefit Accrued to Nigeria due to its Afrocentric Policy of Ensuring Stability in Africa

\subsection{Fostering Unity and Cooperation}

Fostering Unity and Cooperation: This is another benefit accrued to Nigeria for its Afrocentric policy in Africa. The assistance rendered by Nigeria to other African countries will promote the unity and cooperation in the continent (Oni \& Taiwo, 2016). Fostering unity and cooperation in the African continent is one of the objectives set for the AU (AU Constitutive Act, 2002). According to Guzansky (2015) and Suphattanakul (2017), peace and stability is not guarantee where there is no cooperation. This arguably has been one of the motive for Nigeria's action towards fostering unity and cooperation in African continent.

An informant argued in support of the assertion on the need for unity and cooperation in Africa by stressing that "Nigeria is protecting its sovereignty by maintaining peace in Africa and also such has promoted unity in the continent" (Informant BUK). Hence, promotion of unity and cooperation by Nigeria through its contribution to stability and development in Africa could be arguably referred to as an intangible benefit coming to the country. Similarly, informants NIIA1, NIIA2, MFA3 and MFA2 also attested to the relentless contribution of Nigeria as part of the factors that promote the harmonious relationship among the African countries. Their views is equally supported by another informant that:

Without a stable and peaceful continent, the aspiration of having a prosperous, progressive and developed Africa that is free from the words poverty and disease will remain a mirage. The benefit of peace and stability can never be overemphasized for Nigeria and for all other countries. Without 
peace and stability, you can hardly achieve any of the goals or objectives (Informant Unilorin, personal communication, August 28, 2017).

Hence, Nigeria has indirectly assisted the continental organization in Africa, AU in realizing part of its objective of promoting unity and cooperation among the African countries. Figure 1.5. below illustrates a consensus among the interviewees regarding unity and cooperation as a benefit accrued to Nigeria due to its Afrocentric policy of ensuring stability in the African continent.

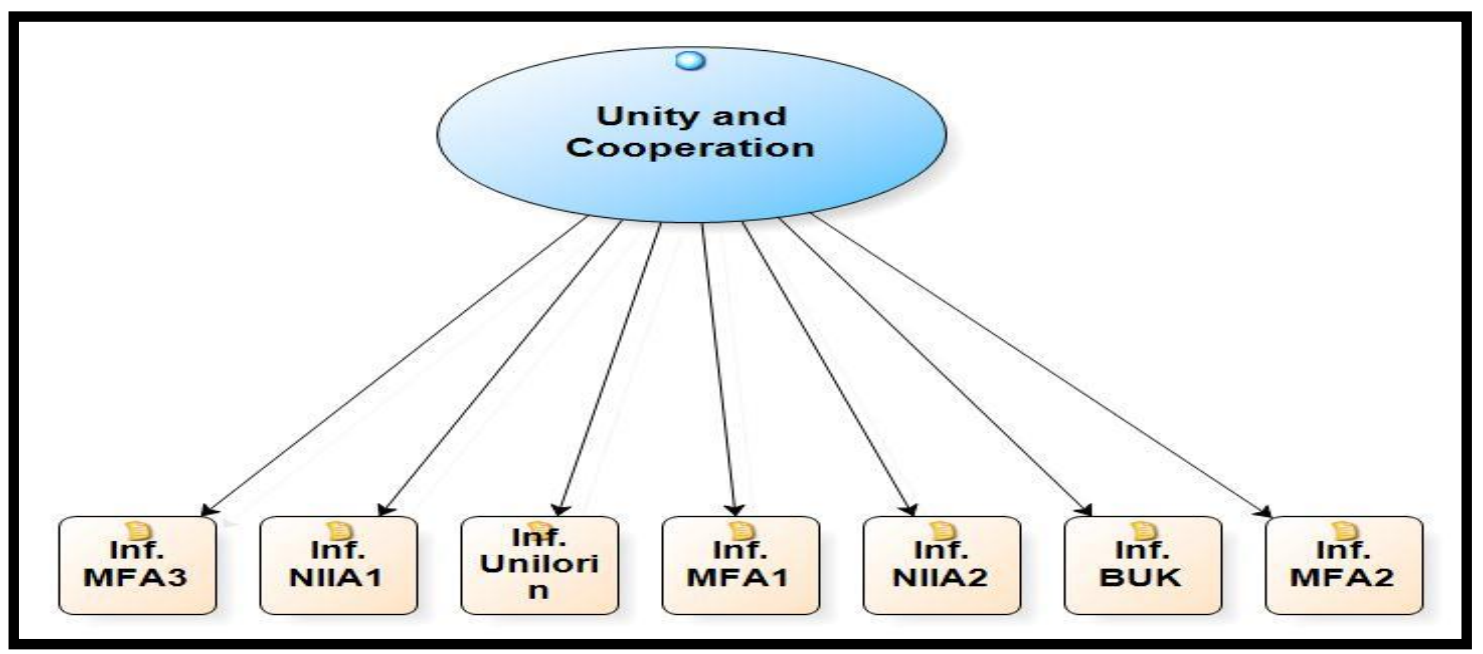

Figure 1.5. Unity and Cooperation as Benefit Accrued to Nigeria due to its Afrocentric Policy of Ensuring Stability in Africa

\subsection{Citizen Diplomacy}

Citizen Diplomacy: This is another benefit accrued to Nigeria for its Afrocentric policy of ensuring stability in African continent. As argued by Marshall (1999), Melissen (1999), La-Porte (2015), Usman and Obiyan (2017), the determinant of the treatment or respect accord to nationals of a country in abroad is measured by the level at which such country is rated by the international community. Meaning that, treatment that will be accorded to Nigerians outside the country is determined by the perception or the level at which the global community rated the country. For a country like Nigeria with a population of over 140 million in year 2006, which also recorded over 190 million in December, 2017 needs to contribute more into Africa's peace and development for its national to be well accorded abroad (Worldometers, 2018). The population figure of Nigeria recorded by the UN Department of Economic and Social Affairs, Population Division has affirmed the claimed that Nigeria is the most populous country in Africa. And that one in every black found anywhere in the world is a Nigeria (Emelumadu, 2010; Ujara \& Ibietan, 2016; Dauda, Ahmad, Keling \& Ameen, 2018).

Similarly, Joseph (2014) argued that a country has the responsibility of protecting the interest of its citizens both at home and abroad. And one of the ways to do so, is to project a good image of ones' country. The view is supported by informants ABU2 and BUK that the aim of Nigerian foreign policy is to ensure that the welfare and security of Nigerians and safeguarding the country's territorial integrity. Doing this through Nigeria's contribution to the development and stability of other African countries, the country's image will the positively projected and its citizens will be accorded well at the international community. Figure 1.6. below shows a consensus among the interviewees regarding citizens diplomacy as a benefit accrued to Nigeria due to its Afrocentric policy of ensuring stability in the African continent. 


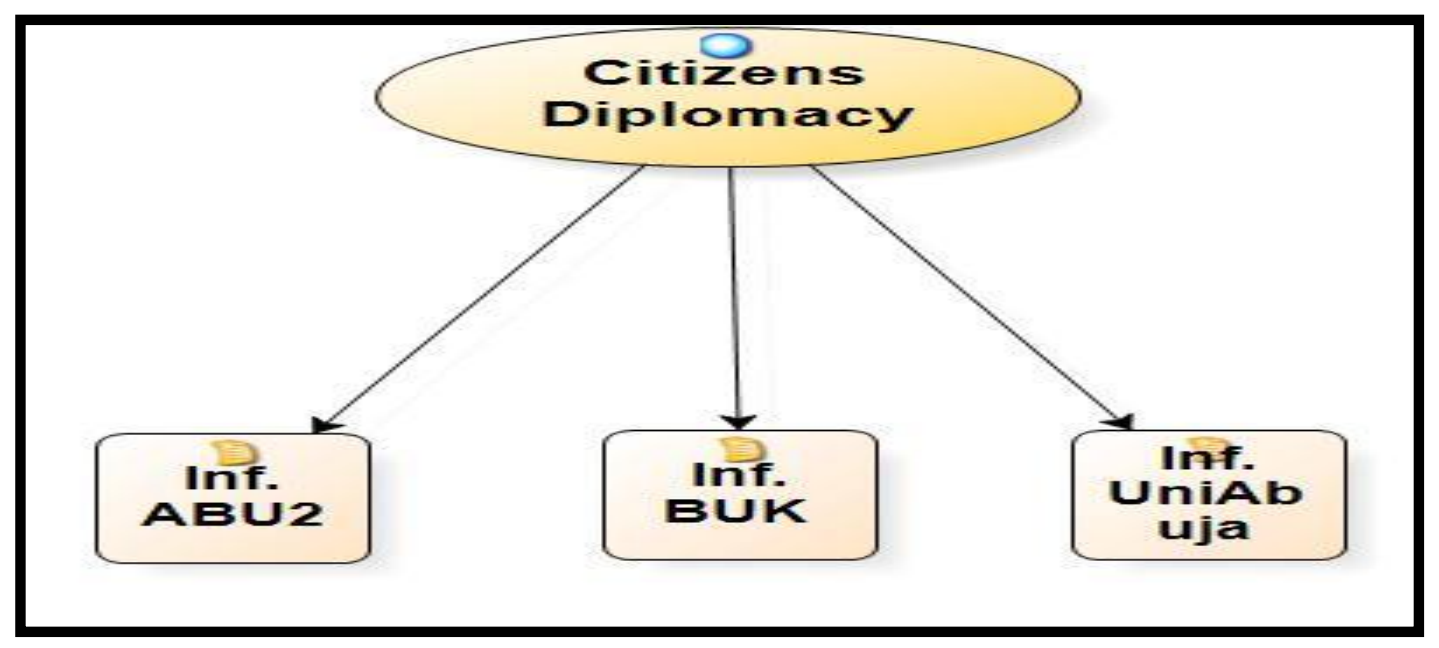

Figure 1.6. Citizens

Diplomacy as Benefit Accrued to Nigeria due to its Afrocentric Policy of Ensuring Stability in Africa

\section{Conclusion}

Foreign policy of Nigeria is one of the tools the country is using to achieve its national interest. Similarly, the concentric nature of Nigeria's external policy has shaped the directions of its policy to be Afrocentric which has made the country to always put Africa's consideration in all its affairs and decisions both locally and internationally. As a result of this, Africa becomes the centre-piece of Nigeria's foreign policy which has made the country to be committed to the development and stability of the African continent. Numerous achievements have been made by Nigeria through its Afrocentric foreign policy to the continent such as unity and cooperation, peace and stability and other developmental facilities which mostly available to areas where there is harmonious relationship. This has in one way or the other assisted the continental organization in Africa, AU to achieve some of its objectives to the continent. By doing this, Nigeria is arguably protecting itself from inheriting the likely consequences of crisis from the conflict zones such as refugees' problem, social vices, militancy, insecurity among others.

Therefore, Nigeria is encouraged to always maximize its benefits to the African continent in order for it to enjoy its own peace. Similarly, there are both tangible and intangible benefits that is accruing to Nigeria for its Afrocentric foreign policy towards ensuring stability and development in Africa. These include security benefit, sovereignty protection, unity and cooperation, citizen diplomacy, international recognition and clout. Apart from the fact that some tangible and intangible benefits coming to Nigeria for its commitment to development and stability of Africa, it also promotes the country's image internationally which is an additional tool or strategy for Nigeria to influence during the decision making at the global arena.

\section{References}

Abdulrasheed, A., Muda, M., \& bin Ahmad, M. Z. (2016). Personality Factor in The Foreign Policy Making: A Case Study of Nigeria Under General Sani Abacha Regime, 1993-1998. International Journal of Management Research and Reviews, Vol. 6(10), pp. 1452-1462.

Achumba, I.C., Ighomereho, O.S. \& Akpor-Robaro, M.O.M. (2013). Security Challenges in Nigeria and the Implications for Business Activities and Sustainable Development. Journal of Economics and Sustainable Development. Vol. 4(2), pp. 79-99.

Adams, K. M., Hester, P. T., \& Bradley, J. M. (2013). A historical perspective of systems theory. Industrial and Systems Engineering Research Conference. Retrievedfrom https://www.researchgate.net/publication/288782223_A_historical_perspective_of_systems theory

Adebajo, A. (2008). Hegemony on a Shoestring: Nigeria's Post-Cold War Foreign Policy. In Adebajo, A. and Mustapha, A.R. (eds.), Gulliver's Troubles: Nigeria's Foreign Policy after the Cold War, (pp. 1-37). Pietermaritzburg: University of KwaZulu-Natal Press.

Adegoju, A. (2014). Person Deixis as Discursive Practice in Nigeria's June 12 Conflict Rhetoric. Ghana Journal of Linguistics. Vol. 3(1), pp. 45-64.

Adeniji, O. (2000). Essay on Nigerian Foreign Policy, Governance and International Security. Ibadan: Dokun Publishers. 
Adesoji A. (2016). Peacekeeping Contributor Profile: Nigeria. Freelance Peace and Security Researcher and Analyst. London: United Kingdom.

Adetula, V. (2015). Nigeria's Response to Transnational Organise Crime and Jihadist Activities in West Africa. Digitala Vetenskapliga Arkivet.

African Union (2002). Constitutive Acts. In AU Handbook. A Guide for those working with and within the African Union. Jointly published by the African Union Commission and New Zealand Ministry of Foreign Affairs and Trade/Manat Aorere. pp. 1-200

Agbu, O., Okereke, E., Wapmuk, S. \& Adeniyi, B. (2013). The Foreign Policy Environment in Nigeria and Implications for Nigeria-South Africa Relations: Baseline Study. Open Society Foundation for South Africa: South African Foreign Policy Initiative. SAFPI Policy Brief No. 54, December.

Ajayi, L., Njoaguani, T., Olorunyomi, B. \& Folarin, S. (2015). Nigeria's Foreign Policy and Codification of National Interest: A Prescriptive Analysis. Covenant University Journal of Politics and International Affairs (CUJPIA). Vol. 3(2), pp. 68-81.

Akinboye, S. O. (2013). Beautiful Abroad but Ugly at Home: Issues and Contradictions in Nigeria's Foreign Policy. Lagos: University of Lagos Inaugural Lecture Series 2013.

Akindele, R. A. (1990). Nigerian Parliament and Foreign Policy, 1960-1966. In G. O. Olusanya, \& R. A. Akindele (Eds.), The Structure and Processes of Foreign Policy Making and Implementation in Nigeria 1960-1990 (pp. 159-173). Ibadan: Vantage Publishers.

Akindele, R. A. (2013). Nigeria's Multilateral Diplomacy, 1960-2012: Structure, Process and Preoccupation. Nigerian Journal of International Studies (NJIS). Vol. 38, pp. 1-68.

Akinterinwa, B.A. (1987). Nigeria's Peace Policy in Chad. May-June, No. 6 \& 7. Accessed on 17th April, 2018. https://www.africaportal.org/documents/7139/Nigerias_Peace_Policy_in_Chad.pdf

Akinyemi, B. (1989). The Colonial Legacy and Major Themes in Nigeria's Foreign Policy. In A. B. Akinyemi, S. O. Agbi, \& A. O. Otubanjo (Eds.), Nigeria Since Independence: The First 25 Years, Vol. X, International Relations (pp. 12-46). Ibadan: Heinemann.

Amuwo, A. S. (2016). Nigeria's Foreign Policy Before Buhari: Global Expectations Amid Domestic and Regional Challenges. A paper presented at a Conference organized by Centre for International Governance Innovation, South African Institute of International Affairs.

Ashaver, B.T. (2014). Concentricism in Nigeria's Foreign Policy. Journal of Humanities and Social Science. Vol. 19(6), pp. 6-11.

Ashiru O. (2014). Nigeria's Foreign Policy: New Realities in a Changing World. In Akinterinwa B.A (ed). Organisation of African Unity/African Union at 50: Nigeria and the Quest for African Unity and Renaissance, Volume Two, (pp. 1-15). Nigerian Institute of International Affairs Press, Lagos, Nigeria.

Ayam, J. (2010). The Challenges and Prospects of Nigerian-United States Relations. In O. C. Eze (Ed.), Beyond 50 Years of Nigeria's Foreign Policy: Issues, Challenges and Prospects (pp. 489-508). Lagos: NIIA.

Badiora, A.I. (2015). Regional Differences and Developmental Implications of Security Challenges in Nigeria: The Case of Kidnapping. Journal of African Security Review. Vol. 24(1), pp. 55-62.

Bassey, C. O. (2011) The Challenge of Military Statecraft in Nigeria", in Bassey C. O. and Dokubo, O. O. (eds), Defence Policy of Nigeria: Capacity and Context, A Reader, Bloomington. Author House.

Bello, I., Dutse, A.I. \& Othman, M.F. (2017). Comparative Analysis of Nigeria Foreign Policy Under Muhammadu Buhari Administration 1983-1985 and 2015-2017. Asia Pacific Journal of Education, Arts and Sciences. Vol. 4(4), 43-52

Boulding, K. E. (1956). General systems theory - the skeleton of science. Management Science. Vol. 2(3), pp. 197208.

Cilliers, J., Schunemann, J., \& Moyer, J. D. (2015). Power and Influence in Africa: Algeria, Egypt, Ethiopia, Nigeria and South Africa. African Futures paper 14, Institute for Security Studies Papers, Vol. 2015(14), pp.1-28.

Collier, P. \& Vicente, P.C. (2014). Votes and Violence: Evidence from a Field Experiment in Nigeria. The Economic Journal. Vol. 124(574), pp. f327-f355.

Constitution of the Federal Republic of Nigeria, 1999 (as amended). Federal Republic of Nigeria.

Dauda, M., \& Ameen, L. (2017). Nigeria's Quest for a United Nations Security Council Permanent Seat: Prospects and Constraints. Asian Journal of Research in Social Sciences and Humanities, Vol. 7(2), pp. 826-841.

Dauda, M., Ahmad M.Z.B. \& Keling, M.F. (2017). Nigeria's Role and Its Peacekeeping Challenges in Africa. An Assessment. European Journal of Social Sciences Studies. Vol. 2(3), pp. 46-71.

Dauda, M., Ahmad M.Z.B., Keling, M.F. \& Ameen, A. (2018). Watchdog Journalism in Nigeria: Democracy and Accountability. Asian People Journal (APJ), Vol. 1(2), pp. 1-20. 
Dauda, M., Sakariyau, R.T. \& Ameen, A. (2018). Xenophobic Violence in South Africa and the Nigerians' Victimization: An Empirical Analysis. Pertanika Journal of Social Sciences \& Humanities, Vol. 26(4), pp. 2677-2700.

Dickson, M.E. \& Ezirim, G.E. (2017). The Political Economy of Recession in Nigeria's Fourth Republic. African Journal of Political Science and International Relations. Vol. 11(7), pp. 193-200.

Durotoye, A. (2015). Obasanjo's Personal Diplomacy, the Liberian Civil War and Charles Taylor's Asylum in Nigeria. International Affairs and Global Strategy. Vol. 36, pp. 19-28.

Dwyer, M. (2015). Peacekeeping Abroad, Trouble Making at Home: Mutinies in West Africa. African Affairs. Vol. 114(455), pp. 206-225.

Emelumadu, C. (2010, June 7). How Important is Nigeria to Africa. BBC World Service Online News. Accessed on 18th April, 2018 - http://www.bbc.co.uk/blogs/africahaveyoursay/2010/06/how-important-is-nigeria-toaf.shtml

Englehart, N.A. (2017). Sovereignty, State Failure and Human Rights: Petty Despots and Exemplary Villains. Routledge: New York.

Enuka, C., \& Odife, I. (2009). The Nigerian Civil War as a Domestic Determinant of Nigeria's Foreign Policy 1967-1975. UJAH: Unizik Journal of Arts and Humanities, Vol. 10(2), pp. 240-250.

Ewoh, A.I.E. (2014). Public Administration Education and Training in Nigeria: Problems, Challenges and Prospects. Journal of Public Affairs Education. Vol. 20(4), pp. 455-468.

Fayomi, O. O., Chidozie, F., \& Yartey-Ajayi, L. (2015). Nigeria's National Image and Her Foreign Policy: An Exploratory Approach. Open Journal of Political Science, Vol. 5, pp. 180-196.

Folarin F.S. (2013). Nigeria and the Dilemma of Global Relevance: Foreign Policy Under Military Dictatorship (1993-1999). Covenant University Journal of Politics and International Affairs (CUJPIA), Vol. 1(1), pp. 21-47.

Franknel, J. (1975). Foreign Policy, 1945-1973. London: Oxford University Press.

Gambari, I. (1986). Nigerian Foreign Policy since Independence. Nigerian Journal of Policy and Strategy, Kuru: National Institute for Policy and Strategic Studies, (pp. 76-89.)

Gambari, I.A. (1989). Theory and Reality in Foreign Policy Making: Nigeria After the Second Republic, New Jersey: Humanities Press International.

Gambari, I.A. (2017). Nigeria: Democray, Development and Foreign Policy. A Memorial Lecture in Honour of Late Professor AbdulRaufu Mustapha on 26th August, at Musa Yar'adua Centre, Abuja, Nigeria.

Goldenziel, J.I. (2017). Displaced: A Proposal for an International Agreement to Protect Refugees Migrants and States. Berkeley Journal of International Law. Vol. 35(1), pp. 47-89.

Guzansky, Y. (2015). The Gulf Cooperation Council: From Cooperation to Unity?. In Guzansky, Y. (ed). The Arab Gulf States and Reform in the Middle East: Between Iran and the Arab Spring (pp. 19-29). Palgrave Pivot, London.

Huntington, S. P. (1997). The erosion of American national interests. Foreign Affairs. Vol. 76(5), pp. 28-49.

Inamete, U. B. (2001). Foreign policy decision-making in Nigeria. Susquehanna University Press.

Innocent, E.O. \& Onyishi, T.O. (2014). Boko Haram and Security Challenges in Nigeria. Kuwait Chapter of the Arabian Journal of Business and Management Review. Vol. 3(11), pp.1-18

Jordaan, E. (2017). Collective Security in Africa: The Tension Between Theory and Practice. Strategic Review for Southern Africa. Vol. 39 (1), pp. 160-184.

Joseph, R. A. (2014). Democracy and Prebendal Politics in Nigeria. Cambridge University Press.

Kabia, J. (2016). Humanitarian Intervention and Conflict Resolution in West Africa: From ECOMOG to ECOMIL. London: Routledge.

Karimi, A., Koosha, A., Asfad, M. N., \& Ansari, M. T. (2017). Examining of Relationship between Responsibility to Protect \& Sovereignty of States in Light of Practice of International Community. Journal of Politics \& Law, Vol. 10, 256-263.

Lanre, A.G. \& Olumide, O.A. (2015). The Pursuance of Nigeria's Domestic and Foreign Policy in the Fourth Republic: Complementarity or Contradiction. Journal of Social Sciences and Humanities. Vol. 1(4), pp. 434-444.

La-Porte, M.T. (2015). The Legitimacy and Effectiveness of Non-State Actors and The Public Diplomacy Concept. Public Diplomacy Theory and Conceptual Issues, April, 1-4, (pp. 1-13). ISA Annual Convention, San Diego,

Leadership Newspaper, (2016, February 12th). Nigeria: Murtala Mohammed's Speech Africa Has Come of Age. Nigerian online Newspaper. Accessed on 28th February, 2018 http://allafrica.com/stories/201602120048.html 
Levy, J.S. (2013). Psychology and Foreign Policy Decision-Making. In Huddy, L., Sears, D.O. and Levy, J.S. (eds). The Oxford Handbook of Political Psychology, (2nd ed.), (pp. 1-33). Oxford University Press.

Marshall Plan Project Group (2017). Africa and Europe: A New Partnership for Development, Peace and a Better Future. Berlin, Germany: Federal Ministry for Economic Cooperation and Development. Accessed on 18th January, 2018

https://www.bmz.de/en/publications/type_of_publication/information_flyer/information_brochures/Materia lie270_africa_marshallplan.pdf

Marshall, P. (1999). Positive Diplomacy. Palgrave Macmillan, London.

McDermott, G. (1973). The Diplomacy and its Apparatus. London: Plume Press Ward Lock Ltd.

Mele, C., Pels, J., \& Polese, F. (2010). A Brief Review of Systems Theories and their Managerial Applications. Service Science. Vol. 2(1-2), pp. 126-135.

Melissen, J. (1999). Innovation in Diplomatic Practice. Palgrave Macmillan, London.

Morgenthau, H. (1978). Politics Among Nations: The Struggle for Power and Peace (5th Edition). New York: Alfred A. Knopf.

Nkem-Onyekpe, J.G. (2015). Politics and Political Power in Nigeria: Nature, Dynamics and Determinants. In Dukor, M. (ed.), Philosophy and Politics: Discourse on Values, Politics, and Power in Africa (pp. 23-36). Lagos Mainland, Nigeria: Malthouse Press Limited.

Northedge, F.S.(ed.) (1968). The Foreign Policies of Powers. London: Faber and Faber.

Nye Jr, J. S. (1999). Redefining the National Interest. Foreign Affairs. Vol. 78(4), pp. 22-35.

Ogunnubi, O. (2017). Effective Hegemonic Influence in Africa: An Analysis of Nigeria's 'Hegemonic' Position. Journal of Asian and African Studies, Vol. 52(7), pp. 932-946.

Ogunnubi, O., \& Isike, C. (2015). Regional hegemonic contention and the asymmetry of soft power: A Comparative Analysis of South Africa and Nigeria. Strategic Review for Southern Africa, Vol. 37(1), pp. 152-177.

Ogunnubi, O., \& Okeke-Uzodike, U. (2016). Can Nigeria be Africa's Hegemon?. African Security Review, Vol. 25(2), pp. 110-128.

Ogunsanwo, A. (1980). Nigerian Military and Foreign Policy, 1975-1979. University of Lagos, Political Science Department.

Ogunsanwo, A. (2007). Citizen Diplomacy: Challenges for Nigeria's Foreig Policy. A Paper Presented at the OneDay Seminar on Citizen Diplomacy organized by the Nigerian Institute of International Affairs, Lagos November, 29.

Ogwu, U. J. (1986). Nigerian Foreign Policy: Alternative Futures. Lagos: The Nigerian Institute of International Affairs.

Ojakorotu, V. \& Adeleke, A. A. (2018). Nigeria and Conflict Resolution in the Sub-regional West Africa: The Quest for a Regional Hegemon? Insight on Africa. Vol. 10(1), pp. 37-53.

Okeke, V.O.S. \& Aniche, E.T. (2013). Internal Political Environment of Nigerian Foreign Policy and Implementation of Citizen Diplomacy Under Yar'Adua/Jonathan Administration (2007-2011): A Linkage Political Approach. American Journal of Social Issues and Humanities. Vol. 4(1), pp.1-12.

Olowu, D. (2017). Governance and Policy Relevance of the Nigerian 40-Year Grassroots Revolution: 1976-2016. International Review of Administrative Sciences. pp. 1-17.

Oni, E.O. \& Taiwo, A.M. (2016). Re-Thinking Nigeria's Foreign Policy Beyond "Big Brotherism Towards Economic Diplomacy. Canadian Journal of Social Science. Vol. 12(10), pp. 62-71.

Osuntokun, J. (2007). Citizen Foreign Policy, and Visa Regime of Embassies in Nigeria. The Nation Newspaper, Lagos: Nigeria.

Ota, E.N. \& Ecoma, C.S. (2015). Nigerian Foreign Policy in a Globalizing World: The Imperative of a Paradigm Shift. Journal of Asian Development. Vol. 1(1), pp. 55-65.

Plischke, E. (1977). Microstates in world affairs: Policy problems and options (Vol. 144). American Enterprise Institute Press.

Saliu, H. A. (1999). Reflections on Four Decades of Nigerian Foreign Policy. Nigerian Journal of International Affairs. Vol. 25, (1\& 2), pp. 93.

Saliu, H. A. (2013). New Options for Nigerian Foreign Policy. Nigerian Journal of International Studies (NJIS). Vol. 38, pp. 167-200.

Satow, E., (1966). A Guide to Diplomatic Practice. London: Longmans, Green and Co. Ltd.

Suphattanakul, O. (2017). Role of Transformational Leadership in Effective Strategic Implementation with the Moderating Effect of Organizational Culture. Journal of Business and Social Review in Emerging Economies, Vol. 3(2), pp. 253-262. 
Tambo, E., Ugwu, E. C. \& Ngogang, J. Y. (2014). Need of surveillance response systems to combat Ebola outbreaks and other emerging infectious diseases in African countries. Infectious Diseases of Poverty. Vol. 3(1), pp. 12-29.

Tyoden, S. (1989). Nigeria, Political Economy and Foreign Policy, 1960-1983. Jos: University Press.

Ujara, E. C. \& Ibietan, J. (2016). Citizen Diplomacy and Nigeria's International Image: The Social Constructivist Explanation. Covenant Journal of Business and Social Sciences. Vol. 6(2), pp. 14-30

Usman, S.A. \& Obiyan, A.S. (2017). Between Afrocentric Foreign Policy Thrust and Domestic National Security Interest: A Review of Nigeria's Intervention in Mali. Accessed on 15th February, 2018 https://ssrn.com/abstract=2967481

Von Bertalanffy, Ludwig, (1974) Perspectives on General System Theory Edited by Edgar Taschdjian. George Braziller, New York

Wapmuk, S. (2014). Nigeria and the Establishment of the OAU and its Transformation to the AU. In Akinterinwa B.A. (ed.). Organisation of African Unity / African Union at 50: Nigeria and the Quest for African Unity and Renaissance, Volume Two (pp. 53-96). Nigerian Institute of International Affairs, Lagos.

Wogu, I.A.P., Sholarin, M.A. \& Chidozie, C.F. (2015). A Critical Evaluation of Nigeria's Foreign Policy at 53. Journal of Research on Humanities and Social Sciences. Vol. 5(2), pp. 137-147.

Worldometers, (2018). Population of Nigeria and Historical. Accessed on 3rd January, 2018. http://www.worldometers.info/

Yunusa, M.H. (2016). Electoral Violence as a Threat to Consolidation of Nigeria's Democracy. Journal of Policy and Development Studies. Vol. 10(3), pp. 58-71.

Yurchenko, S.B. (2017). Logic of Order: State Hierarchy, Law, Sovereignty and War. Journal of International Review of Sociology. Vol. 27(2), pp. 291-318. 